\title{
Pentingnya Pengetahuan Pada Perawat Tentang Keselamatan Pasien Menjadi Issu Terkini Terkait Keselamatan Pasien
}

\author{
Najla Asyah Syafawani Lubis/191101010 \\ najlaasyahsyafawani@gmail.com
}

\section{Latar Belakang}

Isu keselamatan pasien merupakan salah satu isu utama dalam pelayanan kesehatan. Keselamatan (safety) telah menjadi isu global termasuk juga untuk rumah sakit. Ada lima isu penting yang terkait dengan keselamatan (safety) di rumah sakit yaitu: keselamatan pasien (patient safety), keselamatan pekerja atau petugas kesehatan, keselamatan bangunan dan peralatan di rumah sakit yang bisa berdampak terhadap keselamatan pasien dan petugas, kesehatan lingkungan (green productivity) yang berdampak terhadap pencemaran lingkungan dan keselamatan "bisnis" rumah sakit yang berkaitan dengan kelangsungan hidup rumah sakit. Kelima aspek keselamatan tersebut sangatlah penting untuk dilaksanakan di setiap rumah sakit. Namun harus diakui kegiatan institusi Rumah Sakit dapat berjalan apabila ada pasien. Karena itu keselamatan pasien merupakan prioritas utama untuk dilaksanakan dan hal tersebut terkait dengan isu mutu dan Citra perumahsakitan (Putra,2012).

Standar keselamatan pasien wajib diterapkan rumah sakit dan penilaiannya dilakukan dengan menggunakan instrumen akreditasi rumah sakit. Standar keselamatan pasien tersebut terdiri dari 7 standar yaitu: hak pasien, mendidik pasien dan keluarga, keselamatan pasien dan kesinambungan pelayanan, penggunaan metode-metode peningkatan kinerja untuk melakukan evaluasi dan program peningkatan keselamatan, peran kepemimpinan dalam meningkatkan keselamatan pasien, mendidik staf tentang keselamatan pasien, dan komunikasi merupakan kunci bagi staf untuk mencapai keselamatan pasien (Depkes RI, 2008).

Definisi dari keselamatan pasien atau patient safety adalah suatu sistem yang dibuat dalam asuhan pasien di rumah sakit, sehingga pasien menjadi lebih aman, Bila menjalankan sistem ini dengan benar maka pasien terhindar dari terjadinya Cedera yang bisa disebabkan oleh kesalahan akibat melaksanakan suatu tindakan atau tidak mengambil tindakan yang seharusnya diambil. Menurut Depkes (2006) keselamatan pasien di rumah sakit adalah Suatu sistem Dimana rumah 
sakit membuat asuhan bagi pasien sehingga pasien merasa lebih aman. Salah satu tujuan penting dari penerapan sistem keselamatan pasien di rumah sakit adalah mencegah dan mengurangi terjadinya Insiden Keselamatan Pasien (IKP), bahwa dalam pelayanan kesehatan IKP merupakan kejadian atau situasi yang dapat mengakibatkan atau berpotensi mengakibatkan cidera yang seharusnya tidak terjadi. IKP ini meliputi kejadian tidak diharapkan (KTD), kejadian nyaris cedera (KNC), kejadian potensial cedera (KPC), kejadian centinel (KKPRS 2007). Lebih jelas dapat dilihat dalam kepmen nomor 496/Menkes/SK/IV/2005 yang mengatur tentang pedoman audit medis di rumah sakit, di mana tujuan utamanya adalah untuk mencapai pelayanan medis Prima di rumah sakit yang jauh dari medical error dan memberikan keselamatan bagi pasien.

Maka tujuan dilakukannya sistem keselamatan pasien (patient safety) adalah diharapkan tercipta budaya keselamatan pasien di rumah sakit, adanya peningkatan akuntabilitas Rumah Sakit terhadap pasien dan masyarakat, diharapkan terjadi penurunan Adverse Event atau kejadian tidak diharapkan (KTD) dirumah sakit, terlaksananya program-program pencegahan sehingga tidak terjadi pengulangan KTD.

Tenaga perawat merupakan tenaga profesional yang berperan penting dalam fungsi rumah sakit. Hal tersebut didasarkan atas jumlah tenaga perawat sebagai porsi terbesar di dalam pelayanan rumah sakit. Dalam menjalankan fungsinya, perawat merupakan staf yang memiliki kontak terbanyak dengan pasien. Perawat juga merupakan bagian dari suatu tim, yang di dalamnya terdapat berbagai profesi lain seperti dokter. Luasnya peran perawat memungkinkan terjadinya resiko kesalahan pelayanan. Hal-hal tersebut menempatkan peran perawat sebagai komponen penting dalam pelaporan kesalahan pelayanan dalam pengembangan program keselamatan pasien di rumah sakit. Oleh karena itu perlu digali berbagai faktor yang dapat mempengaruhi perawat dalam melaporkan kesalahan pelayanan. Kesalahan praktik keperawatan dapat terjadi dalam tahap pengkajian keperawatan, diagnosa keperawatan, perencanaan keperawatan, pelaksanaan perencanaan keperawatan, evaluasi atau Penilaian proses keperawatan.

Pengetahuan perawat merupakan hal yang berhubungan dengan komitmen yang sangat diperlukan dalam upaya membangun budaya keselamatan pasien (Cahyono, 2008). Pengetahuan adalah salah satu faktor dari manusia yang berpengaruh terhadap kejadian nyaris cidera dan kejadian tidak diharapkan. Patient Safety Merupakan proses dalam rumah sakit yang memberikan pelayanan pasien yang lebih aman. termasuk di dalamnya asesment risiko, 
identifikasi, dan manajemen risiko terhadap pasien, pelaporan dan analisis insiden, kemampuan untuk belajar dan Menindaklanjuti insiden, dan menerapkan solusi untuk mengurangi serta meminimalisir timbulnya risiko (Ariyani, 2008). Jadi sangat penting pengetahuan bagi perawat.

\section{Metode}

Rancangan penugasan kajian ini menggunakan metode literatur review. Dimana metode ini dapat menyelesaikan suatu masalah dengan mengumpulkan data, menganalisa, membandingkan sehingga dapat menentukan pengambilan keputusan dalam masalah tersebut yang berdasarkan dari penjelasan sumber dan referensi yaitu berupa jurnal, ebook atau buku teks.

\section{Hasil}

Berdasarkan hasil penelitian Cahyono, 2015. Pengelompokan tingkat pengetahuan baik dan kurang baik didapatkan hasil diketahui bahwa dari 43 responden perawat yang memiliki pengetahuan kurang berjumlah 13 orang $(30,2 \%)$ dan perawat yang memiliki pengetahuan baik berjumlah 30 orang $(69,7 \%)$. Sebagian besar responden ( $>50 \%$ perawat) memiliki pengetahuan yang baik tentang keselamatan pasien.

Berdasarkan hasil penelitian Sriningsih, \& Marlina, 2020. Pengetahuan tentang patient safety pada petugas kesehatan di Puskesmas Kedaung Wetan Kota Tangerang dengan jumlah responden sebanyak 50 orang dengan pengetahuan tentang patient safety yang tertinggi dalam kategori baik yaitu 31 responden $62 \%$, Berdasarkan penelitian tersebut kita bisa menyimpulkan bahwa petugas kesehatan di Rumah Sakit Puskesmas Kedaung Wetan kota Tangerang banyak dengan pengetahuan tentang patient safety yang tertinggi dalam kategori baik. Hasil penelitian ini sejalan dengan hasil penelitian yang dilakukan oleh Aruningrum, 2014. Hasil penelitian menunjukkan bahwa pengetahuan responden dalam sasaran keselamatan pasien didapat $97 \%$ responden mengetahui identifikasi pasien, $88 \%$ responden mengetahui tentang komunikasi efektif, 99\% responden mengetahui penggunaan obat, 95\% responden mengetahui tentang pengendalian infeksi, dan $70 \%$ responden mengetahui pengendalian resiko jatuh. dari Penjelasan diatas dapat disimpulkan bahwa pengetahuan responden tentang patient safety dalam kategori baik paling tinggi persentasenya. 
Berdasarkan penelitian Futriani \& Hawa, 2018. Pengetahuan perawat tentang keselamatan pasien di Rumah Sakit Masmitra, ari hasil penelitian diketahui sebagian responden memiliki pengetahuan baik yaitu sejumlah 17 responden (56,7\%), sedangkan responden dengan pengetahuan kurang sejumlah 13 responden (43,3\%). Hasil penelitian Aryani, 2008. tentang analisis pengetahuan dan motivasi perawat yang mempengaruhi sikap mendukung penerapan program patient safety Di Instalasi perawatan intensif RSUD Dr Moewardi Surakarta, didapat hasil analisis deskriptif sikap mendukung tinggi (76,3\%), pengetahuan perawat baik $(76,3 \%)$, motivasi perawat baik $(71,1 \%)$.

Berdasarkan penelitian Harus \& Sutriningsih, 2015. Hasil penelitian tentang pengetahuan perawat tentang KPRS di Rumah Sakit Panti Waluya Sawahan Malang menunjukkan sebagian besar responden $(81,7 \%)$ mempunyai pengetahuan yang cukup. Berdasarkan penelitian Ayuni, Almahdi \& Afrianti, 2019. Berdasarkan hasil univariat terhadap pengetahuan perawat dapat dilihat bahwa lebih dari separuh responden memiliki pengetahuan yang rendah dalam pelaksanaan timbang terima $(57,0 \%)$. Berdasarkan hasil penelitian Ramadhani, 2016. pada umum (96\%) perawat mempunyai keterampilan berpikir kritis yang buruk. lebih dari setengah perawat (60\%) mempunyai keterampilan human caring dan relasi sosial baik, dan sebagian besar $80 \%$ perawat mempunyai keterampilan manajemen baik. Sebaliknya sebagian besar $(88 \%)$ perawat juga mempunyai keterampilan kepemimpinan yang buruk. Setengahnya (54\%) perawat mempunyai keterampilan pengajaran yang baik. Dan lebih dari setengah (62\%) mengintegrasikan ilmu pengetahuan.

\section{Pembahasan}

Isu keselamatan pasien merupakan hal yang penting dalam memberi pelayanan kesehatan di Rumah Sakit. Keselamatan pasien merupakan suatu sistem Dimana rumah sakit membuat asuhan pasien lebih aman, mencegah terjadinya cidera disebabkan oleh kesalahan akibat melaksanakan suatu tindakan atau tidak mengambil tindakan yang seharusnya diambil. Pada prinsipnya keselamatan pasien bukan berarti harus tidak ada risiko sama sekali agar semua tindakan medis dapat dilakukan.

Rumah Sakit adalah institusi pelayanan kesehatan bagi masyarakat dengan karakteristik tersendiri yang dipengaruhi oleh perkembangan ilmu pengetahuan kesehatan, kemajuan 
teknologi, dan kehidupan sosial ekonomi masyarakat yang harus tetap mampu meningkatkan pelayanan yang lebih bermutu dan terjangkau oleh masyarakat agar terwujud derajat kesehatan yang setinggi-tingginya, seperti yang dijelaskan dalam undang-undang Kesehatan Nomor 36 Tahun 2009 dan Undang-Undang Rumah Sakit Nomor 44 Tahun 2009 bahwa Rumah Sakit wajib melaksanakan pelayanan kesehatan yang aman, bermutu, anti diskriminasi dan efektif, dengan mengutamakan kepentingan pasien. Rumah Sakit wajib memenuhi hak pasien memperoleh keamanan dan keselamatan selama dalam perawatan di rumah sakit.

Keselamatan adalah suatu sistem yang membuat asuhan pasien lebih aman, meliputi asesment resiko, Identifikasi dan mengelola resiko pasien, pelaporan dan analisis insiden, kemampuan belajar dari insiden dan tindakan lanjutnya, serta Implementasi solusi untuk meminimalkan timbulnya risiko dan mencegah terjadinya Cedera yang disebabkan oleh kesalahan akibat melaksanakan suatu tindakan atau tidak mengambil tindakan yang seharusnya. Suatu jaminan segala tindakan dan aktivitas yang berhubungan dengan pasien yang dilakukan oleh petugas kesehatan agar berlangsung dengan aman. Memberikan Citra yang besar, tanggung jawab sosial moral serta kinerja petugas kesehatan agar mutunya menjadi lebih baik.

Keselamatan pasien merupakan isu global dan nasional bagi rumah sakit, komponen penting dari mutu layanan kesehatan, prinsip dasar dari pelayanan pasien dan komponen kritis dari manajemen mutu (WHO, 2014). Keselamatan pasien akan terus berkembang, yang didefinisikan sebagai upaya maksimal yang dilakukan rumah sakit dalam rangka memberikan pelayanan kesehatan pasien melalui penerapan metode dan regulasi yang legal serta melalui standard yang terukur untuk meminimalisir kesalahan medis. Keselamatan pasien merupakan tanggung jawab semua pihak yang berkaitan dengan pemberi pelayanan kesehatan. Dalam mencapai tujuan yang berorientasi kepada kepuasan pasien, di samping aspek fasilitas Rumah Sakit, peranan dokter, para medis, dan non medis menjadi sangat penting karena kinerja mereka akan menentukan persepsi dan kinerja yang dirasakan pasien terhadap pelayanan yang diberikan. Keselamatan pasien merupakan salah satu indikator kualitas pelayanan kesehatan.

Pelayanan keperawatan menjadi faktor penentu keberhasilan pelayanan kesehatan di Rumah Sakit. Hal ini disebabkan karena tenaga keperawatan merupakan tulang punggung rumah sakit dan subsistem dalam pelayanan kesehatan serta menjadi bagian integral dari pelayanan rumah sakit (Depkes, 2006). salah satu faktor yang mendukung keyakinan tersebut adalah kenyataan 
yang dapat dilihat di unit pelayanan kesehatan rumah sakit, di mana tenaga kesehatan yang selama 24 jam harus berada disisi klien adalah keperawatan. oleh karena itu pelayanan keperawatan berkontribusi dalam menentukan mutu pelayanan di Rumah Sakit, sehingga setiap upaya untuk meningkatkan mutu pelayanan di Rumah Sakit harus disertai upaya meningkatkan mutu pelayanan keperawatan (Triwibowo, 2013).

Praktik keperawatan profesional adalah praktik keperawatan yang diberikan melalui asuhan keperawatan untuk klien, individu, keluarga, masyarakat dan kelompok khusus dalam menyelesaikan masalah kesehatan sederhana sampai komplek baik sehat maupun sakit sepanjang rentang kehidupan manusia. praktik keperawatan di rumah sakit harus dilandasi Aspek etik, legal, dan peka budaya untuk memenuhi kebutuhan klien. (Butler et al, 2011; Carryer, Gardner, Dunn \& Gardner, 2007; Edwards, 2009) perawat harus mempunyai kompetensi sesuai dengan harapan dan kebutuhan klien dalam melakukan asuhan keperawatan pada klien.

Perawat adalah seorang profesional yang mempunyai kemampuan, Tanggung jawab dan kewenangan melaksanakan pelayanan asuhan keperawatan pada berbagai jenjang pelayanan keperawatan. Pemenuhan kebutuhan kepuasan pasien selama di rumah sakit diperlukan tenaga kesehatan yang harus mempunyai pengetahuan (knowledge), keterampilan (skill) yang tinggi serta mempunyai sikap profesional (attitude) dan dapat menunjang pembangunan kesehatan. Pelayanan yang diberikan akan berkualitas dan dapat memberikan kepuasan pada pasien sebagai penerima pelayanan maupun perawat sebagai pemberi pelayanan (Hamid, 2000).

Perawat bekerja dalam berbagai besar spesialisasi di mana mereka bekerja secara independen dan sebagai bagian dari sebuah tim untuk menilai, merencanakan, Menerapkan dan mengevaluasi perawatan. Ilmu keperawatan adalah bidang pengetahuan dibentuk berdasarkan kontribusi dari ilmuwan keperawatan melalui peer-review jurnal ilmiah dan praktik yang dibuktikan berbasis. Ini merupakan bidang yang dinamis praktik dan penelitian yang didasarkan dalam budaya kontemporer dan kekhawatiran itu sendiri dengan baik dan subkultur terpinggirkan dalam rangka untuk memberikan perawatan budaya paling sensitif dan kompeten. Saat ini profesi perawat telah mendapatkan perlindungan hukum melalui disahkannya UU RI Nomor 36 tahun 2014 tentang Keperawatan. Dengan adanya undang-undang ini diharapkan perawat dapat bekerja sesuai peran profesinya secara lebih profesional, bertanggung jawab dan lebih optimal (Siregar, 2016). 
Pada tahun 1982 dewan pusat kesehatan masyarakat (central raad voor de volksgezondheid) telah membuat ketentuan mengenai tindakan apa yang boleh dilakukan oleh perawat yaitu:

1. Tindakan dalam rangka penerusan observasi dan bimbingan pasien selama di rumah sakit.

2. Tindakan perawatan dan pengurusan pasien (verpleging en verzorging).

3. Tindakan di bidang medis yang berhubungan dengan aktivitas diagnostik dan terapi dari dokter dan yang dilaksanakan atas instruksinya.

Pasien atau pesakit adalah seseorang yang menerima perawatan medis. Seringkali, pasien yang menderita penyakit atau cedera dan memerlukan bantuan dokter atau perawat untuk pemulihan nya. Hubungan antara perawat dan pasien bisa merupakan relasi medis dan juga relasi hukum, dalam hal ini disebut kontrak (perjanjian) medis yang bila hanya dalam rangka penyembuhan (kuratif) disebut kontrak terapeutik. Hukum perikatan menyatakan syaratnya suatu persetujuan dan bila ada yang merasa tidak puas atau menimbulkan kerugian (menurut KUH Perdata 1365).

Dalam praktik, Seorang perawat harus membangun relasi dengan pasien sebagai berikut:

1. mengumpulkan data (riwayat kesehatan, dan pemeriksaan fisik dengan hasil laboratorium atau citra medis)

2. menganalisis data

3. membuat rencana perawatan (tes yang harus dijalani berikutnya, terapi, rujukan)

4. merawat pasien

5. memantau, dan menilai jalannya perawatan, dan dapat mengubah perawatan bila diperlukan.

Perawat dalam memberikan asuhan keperawatan kepada pasien harus menerapkan keselamatan pasien. Perawat harus melibatkan kognitif, afektif, dan tindakan yang mengutamakan keselamatan pasien. Perawat dalam memberikan asuhan keperawatan harus dengan penuh kepedulian. Persepsi perawat untuk menjaga keselamatan pasien sangat berperan dalam pencegahan, pengendalian dan peningkatan keselamatan pasien. Pemberi layanan keselamatan berkontribusi terhadap terjadinya kesalahan yang mengancam keselamatan pasien, khususnya perawat, pelayanan terlama ( 24 jam secara terus-menerus) dan tersering berinteraksi pada pasien 
berbagai prosedur dan tindakan keperawatan. Hal ini dapat memberikan peluang yang besar untuk terjadinya kesalahan dan keselamatan pasien.

Perawat dalam melaksanakan keselamatan pasien dipengaruhi oleh faktor internal dan eksternal. Faktor internal merupakan karakteristik perawat yang bersifat bawaan yang teridentifikasi berupa tingkat kecerdasan, tingkat emosional, dan pengalaman pribadi. Faktor eksternal yang mempengaruhi perilaku perawat adalah lingkungan, seperti pengaruh orang lain yang dianggap penting atau kepemimpinan, budaya dan sistem organisasi. Faktor ini sering menjadi faktor dominan yang mewarnai perilaku seseorang. Faktor eksternal berupa pengaruh orang lain juga dapat menimbulkan persepsi perawat terhadap pelaksanaan keselamatan pasien (Siregar, 2016).

Karakteristik dari perawat terdiri dari kemampuan dan keterampilan fisik dan mental dari individu sebagai perawat. Karakteristik ini dipengaruhi juga oleh latar belakang keluarga, tingkat sosial, pengalaman, umur, jenis kelamin, dan etis. Perawat sebagai pekerja memiliki karakteristik individu yang berpengaruh terhadap hasil manajemen. Karakteristik ini dapat memberikan hasil manajemen baik dan tidak baik. Demikian pula dengan tingkat pengetahuan perawat sebagai pekerja, dapat mempengaruhi keterampilan dalam melaksanakan apa yang sudah direncanakan oleh manajemen. (Gibson dalam Yaslis Ilyas, 1999:37).

Pengetahuan adalah fakta, keadaan atau kondisi tentang pengertian mencakup kombinasi dari kesadaran sederhana tentang fakta dan pemahaman tentang bagaimana fakta itu berkaitan satu sama lain (Green, 1980). Tingkat pengetahuan tenaga medis khususnya perawat sangatlah penting dalam melaksanakan asuhan keperawatan. Semakin tinggi pengetahuan perawat tentang kode etik dan hukum kesehatan maka semakin baik pula kinerja perawat dalam melaksanakan asuhan keperawatan. Untuk meningkatkan pengetahuan perawat mengenai kode etik dan hukum kesehatan maka perawat harus membaca buku mengenai kode etik keperawatan dan hukum kesehatan. Selain itu dapat juga melalui teknologi internet serta melalui teman seprofesinya.

Upaya untuk menambahkan tingkat pengetahuan perawat atau tenaga kesehatan yang lain yaitu melalui pelatihan atau seminar. Pelatihan dan seminar dapat bermanfaat untuk melakukan evaluasi terhadap program-program dan standar-standar termasuk standar asuhan keperawatan. Standar asuhan keperawatan harus selalu ditinjau keakuratannya sehingga tidak terjadi suatu 
kesalahan yang dapat merugikan pasien, Selain itu perawat harus dibina untuk mencapai kinerja yang profesional dan bertanggung jawab (Lestari, \& Rosyidah, 2011).

Tingkat pengetahuan yang tinggi akan mempengaruhi kinerja perawat sehingga asuhan keperawatan akan terlaksana dengan baik dan kemungkinan terjadinya malpraktik atau kelalaian rendah. Hal ini terjadi karena perawat atau tenaga medis telah dibekali dengan pengetahuan tentang etika dan dan keselamatan pasien (patient safety). Kinerja perawat dipengaruhi oleh faktor balas jasa yang adil dan layak, penempatan yang sesuai dengan keahliannya, berat ringan pekerjaannya, lingkungan, peralatan yang menunjang, serta sikap pimpinan dalam memberikan bimbingan dan pembinaan. Oleh karena itu, sangat penting pengetahuan pada perawat untuk penerapan keselamatan pasien.

\section{Kesimpulan}

Pengetahuan merupakan domain yang sangat penting untuk terbentuknya tindakan seseorang. pengetahuan diperlukan sebagai dukungan dalam menumbuhkan rasa percaya diri maupun sikap dan perilaku, sehingga pengetahuan merupakan Fakta yang mendukung tindakan seseorang. pengetahuan pada perawat tentang keselamatan pasien (patient safety) merupakan hal yang penting, karena jika pengetahuan perawat tentang keselamatan pasien kurang maka jelas ini akan berpengaruh terhadap kinerja perawat itu sendiri dalam penerapan keselamatan pasien di rumah sakit. peningkatan pengetahuan merupakan dampak yang diharapkan dari pelatihan mutu dan keselamatan pasien. Pelatihan merupakan salah satu sarana menambah kebutuhan akan pengetahuan baru dan untuk meningkatkan kinerja individu dan kinerja sistem.

\section{Daftar Pustaka}

Ayuni, D, Q., Almahdy., \& Afriyanti, E. (2019). Analisis Faktor-Faktor Yang Berhubungan Dengan Pelaksanaan Timbang Terima Pasien Di Ruang Rawat Inap Rumah Sakit Umum Daerah Pariaman. Jurnal Ilmu Keperawatan Dan Kebidanan, 10 (1), 163-172.

Bawelle, S, C., Sinolungan, J, S, V., \& Hamel, R, S. (2013). Hungan Pengetahuan Dan Sikap Perawat Dengan Pelaksanaan Keselamatan Pasien (Patient safety) Di Ruang Rawat Inap RSUD Liun Kendange Tahuna. Ejournal Keperawatan (e-Kp), 1 (1), 1-7. 
Cahyono, A. (2015). Hubungan Karakteristik Dan Tingkat Pengetahuan Perawat Terhadap Pengelolahan Keselamatan Pasien Di Rumah Sakit. Jurnal Ilmiah WIDYA, 3 (2), 97-102.

Futriani, E, S., \& Hawa, S. (2018). Hubungan Pengetahuan Dan Sikap Dengan Penerapan Standar Keselamatan Pasien Di Instansi Perawatan Intensif. Jurnal Antara Keperawatan, 1 (1), 30-37.

Hadi, I. (2017). Manajemen Keselamatan Pasien. Yogyakarta: Deepublish.

Harus, B, D., \& Sutriningsih, A. (2015). Pengetahuan Perawat Tentang Keselamatan Pasien Dengan Pelaksaan Prosedur Keselamtan Pasien Rumah Sakit (KPRS) Dirumah Sakit Panti Waluya Sawahan Malang. Jurnal CARE, 3 (1), 25-32.

Iriviranty, A. (2015). Analisis Budaya Organisasi Dan Budaya Keselamatan Pasien Sebagai Langkah Pengembangan Keselamatan Pasien Di RSIA Budi Kemuliaan Tahun 2014. Jurnal Adminstasi Rumah Sakit, 1 (3), 196-206.

Mandriani, E., Hardisman., \& Yetti, H. (2019). Analisis Dimensi Budaya Keselamatan Pasien Oleh Petugas Kesehatan Di RSUD dr Rasidin Padang Tahun 2018. Jurnal Kesehatan Andalas, 8 (1), 131-137.

Mudayana, A, A. (2014). Peran Etika Tenaga Medis Dalam Penerapan Budaya Keselamatan Pasien Di Rumah Sakit. Supplemen Majalah Kedokteran Andalas, 37 (1), 69-74.

Rahmadhani, D, Y. (2016). Analisis Pendekatan Model COPA Dan Faktor Determinan Pada Perawat Pelaksana Dengan Keselamatan Pasien Di Rumah Sakit Abdul Manap Kota Jambi. Scientia Journal, 5 (1), 46-57.

Safitri, W., \& Ati, A, M. (2018). Tingkat Pengetahuan dengan Sikap Dan Praktik Perawat Dalam Implementasi Patient Safety: Risiko Jatuh Di RSUD Dr. Soehadi Briedjonegoro Sragen. Adi Husada Nursing Journal, 4 (1), 28-32.

Simamora, R. H., \& Nurmaini, C. T. S. (2019). Knowledge of Nurses about Prevention of Patient Fall Risk in Inpatient Room of Private Hospital in Medan. Indian Journal of Public Health Research \& Development, 10(10), 759-763. 
Siregar, R, A. (2016). Hubungan Perawat Dan Pasien: Implementasi Standar Keselamatan Pasien. Jurnal Hukum to-ra, 2 (1), 295-304.

Sriningsih, N., \& Marlina, E. (2020). Pengetahuan Penerapan Keselamatan Pasien (Patient Safety) Pada Petugas Kesehatan. Jurnal Kesehatan, 9 (1).

Wardhani, V. (2017). Buku Ajar- Manajemen Keselamatan Pasien. UB Press. 